Original Research Paper

\title{
Effect of Heavy Metals on the Enzymatic Activity of Haplic Chernozem under Model Experimental Conditions
}

\author{
${ }^{1}$ Natalia Gromakova, ${ }^{1}$ Saglara Mandzhieva, ${ }^{1}$ Tatiana Minkina, \\ ${ }^{1}$ Olga Birukova, ${ }^{1}$ Sergey Kolesnikov, ${ }^{2}$ Galina Motuzova, ${ }^{1}$ Victor Chaplygin, \\ ${ }^{2}$ Natalia Barsova, ${ }^{1}$ Inna Zamulina, ${ }^{1}$ Svetlana Sushkova and ${ }^{1}$ Yurii Litvinov \\ ${ }^{I}$ Department of Soil Science and Land Evaluation, Southern Federal University, Rostov-on-Don, Russia \\ ${ }^{2}$ Faculty of Soil Science, Moscow State University, Moscow, Russia
}

Article history

Received: 15-03-2017

Revised: 21-06-2017

Accepted: 22-07-2017

\section{Corresponding Author:}

Saglara Mandzhieva

Department of Soil science and

Land Evaluation, Southern

Federal University, Rostov-on-

Don, Russia

E-mail : msaglara@mail.ru

\begin{abstract}
The biological activity of soils is an essential parameter of their ecological status. The anthropogenic Heavy Metals (HMs) disturb the normal functioning of soil biota and, hence, the entire soil system. The aim of this work was to estimate the toxicity of loosely bound HM compounds in Haplic Chernozem using parameters of cellulose-degrading and urease activities. Contamination of Haplic Chernozem with $\mathrm{Zn}, \mathrm{Cd}, \mathrm{Cu}$ and $\mathrm{Pb}$ enlarged the group of mobile (loosely bound to soil) metal compounds, which includes exchangeable, complexed and specifically sorbed compounds of HMs. The increase of mobile HM forms content in soil inhibited the cellulose-degrading and urease activities after 30 days of the input of metal into the soil. A decrease in the toxic effect of metals on the studied parameters mainly occurred in the next 30 days. It was found that all HM forms similarly affected biological activity parameters. During two months from the moment of soil contamination with HMs, their toxic effect on cellulose-degrading and urease activities decreased. According to the degree of inhibition of biological activity in Haplic Chernozem, the studied metals formed the following series: $\mathrm{Cd}>\mathrm{Pb}>\mathrm{Zn}>\mathrm{Cu}$.
\end{abstract}

Keywords: Heavy Metals, Soils, Enzyme Activity, Pollution

\section{Introduction}

Soils, which are open buffer systems, need monitoring of their status under varying ecological conditions. Chemical contamination is frequently due to the input of Heavy Metals (HMs) into the soil. The specific ability of soil to sorb and distribute the arriving HMs among its components determines the state of the entire ecosystem of current interest is an objective estimation of the ecological status of soils, which is reduced to the revelation of factors determining the toxicity level of the contamination (Chaplygin et al., 2014; Minkina et al., 2015; 2017a; Hu et al., 2014; Mandzhieva et al., 2014). The biological activity of soils is an essential parameter of their ecological status. This parameter is characterized by a significant variation under the effect of diverse factors. The anthropogenic HMs disturb the normal functioning of soil biota and, hence, the entire soil system (Belyaeva, 2002; Gukalov et al., 2015; Mineev et al., 2008; Moreno et al., 2009).

The current interest in the effect of HMs on soil microorganisms is related to the fact that the mineralization of organic residues, which ensures the integration of the biological and geological cycles, is mainly concentrated in the soil.
The use of bioindicators (cellulose-degrading and urease activities) is an objective and reliable approach to estimating the toxicity of HM forms in the soil. The biochemical and ecological conditions of pedogenesis, the intensity of biochemical processes in the soil and the fertility and biological activity of soil reflect the soil enzymes (Usman et al., 2016; Naplekova and Stepanova, 1981; Nedyalkova et al., 2017; Shlevkova, 1993). It was noted (Bardina et al., 2013; Shipilina, 1996) that nitrifying and cellulose-degrading bacteria are the most vulnerable components of soil biota. Changes in their abundance can be indicative of the biological status of HMcontaminated soils. The activity of cellulose-degrading bacteria depends on the presence of mobile HMs in the soil and the degree of degradation of cellulose reflects the general direction of microbiological processes.

Changes in enzyme activity are indicators for the early diagnosis of negative changes in soil properties (Galstyan, 1982; Khaziev, 1982; Sardar, 2007; Vodyanitskii, 2014; Zvyagintsev, 2001). The inhibiting effect of HMs on enzymes is due to their complexation with proteins. Metal cations have a high affinity for the sulfhydryl groups of proteins, are coordinated with the imidazole nitrogen of histidine residues and carbonyl and carboxyl oxygen and form stable chelate bioclusters. Lead 
cations are characterized by the displacement of the metal from the active site of the metalloenzyme (Ershov, 2005).

Model experiments (Kolesnikov et al., 2006; 2013) revealed the following sensitivity series of enzymes to the effect of HMs in Haplic Chernozem: Urease > invertase $>$ dehydrogenases $>$ catalase. The determination of urease activity in soils is characterized by high informatively, sensitivity and specificity, as well as good reproducibility of results and, hence, low experimental error, high speed and wide distribution of the method, which provides comparable results. The inhibition of urease by HMs proceeds in two stages: Initial and prolonged inhibition. The initial inhibition shows the degree of inactivation of urease present in the soil (rapid response of the enzyme to contamination). The prolonged inhibition reflects a number of processes occurring in the soil such as the binding of metal cations by soil particles, including molecules of nutrition substrate, the inhibition of the microbiological fraction of soil, etc.

A direct correlation is observed between the content of HMs and the degree of changes in the biological properties of soil. According to the deterioration of biological properties under contamination with HMs, chernozems of southern Russia form the following series: Ordinary chernozem $=$ Ordinary (northern-Azov) chernozem = Ordinary (Ciscaucasian) chernozem > typical (mountain) chernozem $>$ typical (piedmont) chernozem $>$ typical (Ciscaucasian) chernozem = Southern chernozem $=$ Southern (chestnut) chernozem >> leached vertic chernozem (Kolesnikov et al., 2013).

The effect of HMs on the biological activity of chernozemic soils was studied by many authors (Belyaeva, 2002; Kolesnikov et al., 2006; 2014; Naplekova and Stepanova, 1981; Shlevkova, 1993). The distribution of HMs arriving into the soil and the effect of their toxic forms on soil biota are of interest. To estimate the toxicity of HMs in soils, it was proposed to analyze the group composition of their compounds using a combined fractionation scheme. This approach allows determining the mobility of HMs in soils from their distribution between the groups of compounds strongly and loosely bound to the soil. The group of loosely bound metal compounds includes exchangeable, complexed and specifically sorbed metal forms. The aim of this work was to estimate the toxicity of loosely bound HM compounds in Haplic Chernozem using parameters of cellulose-degrading and urease activities.

\section{Materials and Methods}

The object of study was deep low-humus heavy loamy calcareous ordinary chernozem (Haplic Chernozem) on loess-like loam. Soil was sampled in the Donskoe training farm located in the Oktyabr'skii district of the Rostov oblast (Russia). Soil samples were taken from a depth of 0-20 cm. Soil properties are given in Table 1.

Pots were filled with soil preliminarily sieved through a $1 \mathrm{~mm}$ sieve and contaminated with HMs; the weight of soil in each pot was $3 \mathrm{~kg}$. Solutions of $\mathrm{Zn}, \mathrm{Cd}$, $\mathrm{Cu}$ and $\mathrm{Pb}$ acetates were added to the soil separately. The water content was $60 \%$ of maximum water capacity; temperature was $20-22^{\circ} \mathrm{C}$.

The experimental design included the contamination treatments ranked in order of Maximum Permissible Concentration (MPC) for total metals in the soil (100 for $\mathrm{Zn}, 55$ for $\mathrm{Cu}, 32$ for $\mathrm{Pb}, 0.5 \mathrm{mg} / \mathrm{kg}$ for $\mathrm{Cd}$ ) (Artyushin et al., 1992): (1) control without pollutant; (2) $1 \mathrm{MPC}$; (3) $2 \mathrm{MPC}$; (4) $5 \mathrm{MPC}$; and (5) $10 \mathrm{MPC}$. Experiments were performed in triplicate.

The ecological status of the studied soils was estimated from their biological activity parameters, total HM contents, HM retention strength and the content of loosely bound metal compounds.

The total HM contents were determined by X-ray fluorescence analysis. It was proposed to subdivide HMs in soils into two groups: Strongly and loosely bound to the soil (Minkina et al., 2008). It is advisable to determine the content of HM groups in soils for estimating their mobilities and abilities of passing to adjacent environments. The group of loosely bound compounds includes exchangeable, complexed and specifically sorbed metal forms. The binding strength of metals by soil components was determined using the methods based on the parallel extraction of metal compounds with the following extractants:

- Ammonium acetate buffer solution (1 N $\left.\mathrm{CH}_{3} \mathrm{COONH}_{4}\right)(\mathrm{AAB}$ ) with $\mathrm{pH} 4.8$ (soil: Solution $=1$ : 5 ; time of extraction $18 \mathrm{~h}$ ). Metal compounds extracted by $\mathrm{AAB}$ are classified as exchangeable forms

- $\quad$ EDTA + AAB (1\% solution of EDTA in AAB; soil: Solution $=1: 5$; time of extraction $18 \mathrm{~h}$ ). This solution presumably extracted exchangeable metal forms and those bound into organ mineral complexes. Consequently, the difference between the contents of metals in the (EDTA $+\mathrm{AAB})$ and $\mathrm{AAB}$ solutions characterized the metal compounds bound into organ mineral complexes: So-called complex HM compounds

- $\quad 1 \mathrm{~N} \mathrm{HCl}$ (soil: Solution = 1: 10; time of extraction 1 h). Along with exchangeable forms, this reagent solubilized specifically sorbed metal compounds, which mainly include metals relatively loosely retained by iron, aluminum and manganese oxides and hydroxides and carbonates. The difference between the contents of metals extracted by $1 \mathrm{~N} \mathrm{HCl}$ and $\mathrm{AAB}$ is defined as specifically sorbed forms (Minkina et al., 2008)

The content of metals in strongly bound compounds with organic and mineral components was calculated from the difference between the contents of total metals and their loosely bound forms in the soil. The relative content of loosely bound HM compounds in the soil characterized the mobility of the metal. 
Table 1. Physicochemical and agrochemical properties of ordinary chernozem (0 - to 20 -cm layer $)$

\begin{tabular}{lllllllllll}
\hline $\begin{array}{l}\text { Humus, } \\
\text { \% }\end{array}$ & $\mathrm{pH}$ & $\begin{array}{l}\text { Physical } \\
\text { clay, } \%\end{array}$ & $\begin{array}{l}\text { Clay, } \\
\%\end{array}$ & $\begin{array}{l}\mathrm{CaCO}_{3}, \\
\%\end{array}$ & $\begin{array}{l}\mathrm{CEC}, \\
\mathrm{cmol}(+) / \mathrm{kg}\end{array}$ & $\begin{array}{l}\mathrm{Ca}^{2+}, \\
\mathrm{cmol}(+) / \mathrm{kg}\end{array}$ & $\begin{array}{l}\mathrm{Mg}^{2+}, \\
\mathrm{cmol}(+) / \mathrm{kg}\end{array}$ & $\begin{array}{l}\mathrm{Na}^{+}, \\
\mathrm{cmol}(+) / \mathrm{kg}\end{array}$ & $\begin{array}{l}\mathrm{K}_{\text {ex }}, \\
\mathrm{mg} / \mathrm{kg}\end{array}$ & $\begin{array}{l}\mathrm{P}_{2} \mathrm{O}_{5}, \\
\mathrm{mg} / \mathrm{kg}\end{array}$ \\
\hline 6.6 & 7.2 & 48.1 & 28.6 & 0.1 & 371 & 310 & 45 & 1 & 228 & 16 \\
\hline
\end{tabular}

Cellulose-degrading activity was analyzed by the application method from the degradation of linen fabric (Dobrovol'skaya et al., 2015); the activity of urease was determined by the Khaziev (1990) method. The cellulose-degrading and urease activities were estimated 30 and 60 days after the contamination of soil with HMs. To estimate the activity of cellulose-degrading organisms, linen fabric was taken out of the soil after 30 days and the decomposition intensity of fabric was analyzed. New linen fabrics were placed in the same pots and analyzed after next 30 days to estimate the results of composting for post 30 days.

All analyzes were performed in triplicate. The interpretation of results was performed using variance and correlation-regression analysis.

\section{Results and Discussion}

The total contents of $\mathrm{Pb}, \mathrm{Cu}, \mathrm{Cd}$ and $\mathrm{Zn}$ in uncontaminated Haplic Chernozem did not exceed the MPCs for these elements except Cd Table 2. This could be related to the fact that the existing norms do not take into account the regional features of soils.

The content of total HMs is a capacity factor, which reflects the potential hazard of contamination for terrestrial ecosystems and characterizes the total content of elements in the soil but gives no idea of HM availability for plants and hydrobionts. The loosely bound HMs compounds are the most active nutrients for living organisms and contamination agents. The content of loosely bound HMs in the soil has a higher information value (Minkina et al., 2017b).

Determination of loosely metal compounds in control variant showed that the contents of the exchangeable forms of the studied metals did not exceed of the MPC for $\mathrm{Cu}, \mathrm{Pb}, \mathrm{Zn}$ and $\mathrm{Cd}$ Table 2. According to the contents of exchangeable forms ( $\%$ of total content) in the studied soils, the metals form the following descending series: $\mathrm{Cd}>\mathrm{Pb}>\mathrm{Cu}=\mathrm{Zn}$. At the addition of metals to the soil, the exchangeable HM content increased in 3 to 15 times (Table 2 and Fig. 1). The largest increase was noted at $\mathrm{Pb}$ (in 15.23 times). Under contamination conditions an increase in the proportions of complexed forms of HM in the group of loosely bound compounds was noted for all studied metals (Table 3).

The content of complex forms of HM in unpolluted soil was lower than that of exchangeable forms, with the exception of $\mathrm{Cd}$. The number of exchangeable and complex forms of $\mathrm{Cd}$ was the same. According to the relative contents of complexed forms ( $\%$ of total content) in soils without pollutants, the HMs form the following series: $\mathrm{Cd}>\mathrm{Pb}>\mathrm{Cu}=\mathrm{Zn}$. In all contamination treatments an increase in the proportions of complexed forms of HM in the group of loosely bound compounds was noted for $\mathrm{Cu}$ and $\mathrm{Pb}$ Table 3, which is related to the capacity of these metals to form complex compounds with soil organic matter.

The content of specifically sorbed forms of HM in Haplic Chernozem was higher than exchangeable and complexed forms. In the studied unpolluted soil, the relative contents ( $\%$ from total content) of specifically sorbed elements form the following series: $\mathrm{Pb}>\mathrm{Cu}>$ $\mathrm{Cd}>\mathrm{Zn}$. At the addition of metals to the soil, the specifically sorbed HM content increased in 3.8 to 53.3 times Table 2. The specifically sorbed metals make up the highest proportion of loosely bound metal compounds in polluted and unpolluted and compose their potential reserve Table 3 .

The initial contents of loosely bound metal forms in Haplic Chernozem were low. All of the studied metals predominantly occurred in the form of strongly bound compounds (83-93\%). Consequently, $7-17 \%$ of HMs formed loosely bound compounds. In the uncontaminated background soil, $\mathrm{Cd}$ was the most mobile metal: Its contribution to the group of loosely bound compounds was $17 \%$; $\mathrm{Cu}$ was less mobile: The share of its loosely bound compounds was $7 \%$. In the group of loosely bound HM compounds, the share of specifically bound forms was $40-89 \%$. The lowest content of specifically sorbed compounds was found for $\mathrm{Cd}$, which suggests that this is the most mobile HM in soil, with consideration for the highest share of its loosely bound compounds ( $17 \%$ of the total metal content).

Contamination of soil with HMs increased the group of loosely bound compounds and affected the proportions of metal forms within the group. In the experimental treatments, the contents of loosely bound $\mathrm{Pb}, \mathrm{Cd}, \mathrm{Cu}$ and $\mathrm{Zn}$ compounds increased in accordance with their application rates.

The artificial contamination of soil with $\mathrm{Pb}$ increased the share of mobile metal forms already in the treatment with 2 MPC. At this application rate, the content of the group of loosely bound $\mathrm{Pb}$ compounds was 3 times higher than in the control. When the contamination of soil with lead increased, the metal mobility and, hence, the share of loosely bound compounds also increased. At the supplication rate of $5 \mathrm{MPC}$, the share of loosely bound $\mathrm{Pb}$ compounds exceeded that of strongly bound forms; in the treatment with $10 \mathrm{MPC}$, it reached $64 \%$.

The increase in the content of loosely bound $\mathrm{Pb}$ compounds in the soil was mainly due to the increase in the share of the most mobile exchangeable and complexed metal forms. This was confirmed by the increase in the share of these forms in the group of loosely bound $\mathrm{Pb}$ compounds Table 3 . 
Natalia Gromakova et al. / OnLine Journal of Biological Sciences 2017, 17 (3): 143.150 DOI: 10.3844/ojbsci.2017.143.150

Table 2. Total contents, form distributions and relative contents of loosely bound HM compounds in

\begin{tabular}{|c|c|c|c|c|c|}
\hline \multirow[b]{2}{*}{$\begin{array}{l}\text { Experimental } \\
\text { treatment }\end{array}$} & \multicolumn{5}{|l|}{$\mathrm{mg} / \mathrm{kg}$} \\
\hline & $\begin{array}{l}\text { Total } \\
\text { content }\end{array}$ & $\begin{array}{l}\text { Exchangeable } \\
\text { forms }\end{array}$ & $\begin{array}{l}\text { Complexed } \\
\text { forms }\end{array}$ & $\begin{array}{l}\text { Specifically } \\
\text { sorbed forms }\end{array}$ & $\begin{array}{l}\text { Loosely bound forms } \\
\% \text { of total content }\end{array}$ \\
\hline \multicolumn{6}{|l|}{$\overline{\mathrm{Pb}}$} \\
\hline Control & 24.97 & 0.33 & 0.25 & 2.17 & 11 \\
\hline $1 \mathrm{MPC}$ & 52.17 & 1.00 & 0.75 & 4.51 & 12 \\
\hline $2 \mathrm{MPC}$ & 82.50 & 7.27 & 3.91 & 16.77 & 34 \\
\hline $5 \mathrm{MPC}$ & 176.91 & 32.15 & 18.08 & 50.23 & 58 \\
\hline $10 \mathrm{MPC}$ & 359.65 & 71.13 & 39.00 & 119.31 & 64 \\
\hline $\mathrm{LSD}_{095}$ & 12.18 & 0.86 & 1.19 & 3.30 & \\
\hline \multicolumn{6}{|l|}{$\mathrm{Cd}$} \\
\hline Control & 0.58 & 0.04 & 0.04 & 0.02 & 17 \\
\hline $1 \mathrm{MPC}$ & 1.16 & 0.16 & 0.14 & 0.13 & 36 \\
\hline $2 \mathrm{MPC}$ & 1.38 & 0.27 & 0.20 & 0.10 & 38 \\
\hline 5 MPC & 3.10 & 0.50 & 0.40 & 0.33 & 41 \\
\hline $10 \mathrm{MPC}$ & 5.23 & 0.90 & 0.93 & 0.70 & 46 \\
\hline $\mathrm{LSD}_{095}$ & 0.56 & 0.25 & 0.13 & 0.11 & \\
\hline \multicolumn{6}{|l|}{$\mathrm{Cu}$} \\
\hline Control & 46.10 & 0.39 & 0.29 & 2.55 & 7 \\
\hline $1 \mathrm{MPC}$ & 97.79 & 1.64 & 2.81 & 18.95 & 24 \\
\hline $2 \mathrm{MPC}$ & 162.78 & 4.70 & 4.23 & 38.10 & 29 \\
\hline $5 \mathrm{MPC}$ & 306.53 & 46.63 & 28.69 & 104.01 & 58 \\
\hline $10 \mathrm{MPC}$ & 535.76 & 75.76 & 54.86 & 130.63 & 50 \\
\hline $\mathrm{LSD}_{095}$ & 18.95 & 1.39 & 0.83 & 12.27 & \\
\hline \multicolumn{6}{|l|}{$\mathrm{Zn}$} \\
\hline Control & 58.33 & 0.49 & 0.28 & 6.23 & 12 \\
\hline $1 \mathrm{MPC}$ & 149.78 & 1.89 & 2.51 & 27.04 & 21 \\
\hline $2 \mathrm{MPC}$ & 264.89 & 4.90 & 3.68 & 52.69 & 23 \\
\hline $5 \mathrm{MPC}$ & 561.52 & 60.03 & 47.17 & 252.76 & 64 \\
\hline $10 \mathrm{MPC}$ & 1041.90 & 153.21 & 114.91 & 331.95 & 57 \\
\hline $\mathrm{LSD}_{095}$ & 21.76 & 1.92 & 15.85 & 11.55 & \\
\hline
\end{tabular}

Table 3. Distribution of HM forms in the group of loosely bound compounds in calcareous ordinary chernozem, $\%$

\begin{tabular}{lccc}
\hline Experimental treatment & Exchangeable forms & Complexed forms & Specifically sorbed forms \\
\hline Pb & 6.9 & 4.0 & 89.1 \\
Control & 7.3 & 8.0 & 84.7 \\
1 MPC & 8.0 & 6.0 & 86.0 \\
2 MPC & 14.0 & 6.0 & 80.0 \\
5 MPC & 24.0 & 21.0 & 55.0 \\
10 MPC & & & 40.0 \\
Cd & 20.0 & 40.0 & 39.5 \\
Control & 27.9 & 32.6 & 28.1 \\
1 MPC & 36.8 & 35.1 & 26.6 \\
2 MPC & 40.7 & 32.8 & 20.7 \\
5 MPC & 42.6 & 36.9 & 78.9 \\
10 MPC & & & 81.0 \\
Cu & 9.0 & 12.1 & 81.0 \\
Control & 12.0 & 7.0 & 58.0 \\
1 MPC & 9.0 & 10.0 & 50.0 \\
2 MPC & 16.0 & 26.0 & 65.1 \\
5 MPC & 21.0 & 29.0 & 67.0 \\
10 MPC & & & 70.0 \\
Zn & 4.1 & 31.0 & 72.0 \\
Control & 7.0 & 26.0 & 72.0 \\
1 MPC & 12.0 & 18.0 & \\
2 MPC & 17.0 & 11.0 & 7.0 \\
5 MPC & 21.0 & & \\
10 MPC & & 7.0 & \\
\hline & & &
\end{tabular}


Cadmium is the most mobile element in the soil. The share of its mobile compounds in the control soil was $17 \%$, including $20 \%$ of them in exchangeable forms and $40 \%$ in complexed forms. The contamination of soil with $\mathrm{Cd}$ was characterized by the most significant increase in its mobility. For example, an almost double increase in the content of loosely bound compounds was noted already at the metal application at 1 MPC Table 2. In the treatment with the application of 100 MPC, the share of loosely bound metal compounds increased in more than 7 times compared to the original soil. A significant increase in the share of exchangeable $\mathrm{Cd}$ forms was noted in the group of loosely bound compounds, which enhanced the metal mobility.

The total $\mathrm{Cu}$ content in the control soil did not exceed the MPC and corresponded to the background content of the element in Haplic Chernozem (Motuzova et al., 2014; Mandzhieva et al., 2014). The share of strongly bound $\mathrm{Cu}$ compounds was $93 \%$. The application of $\mathrm{Cu}$ at a rate of 1 MPC increased the metal mobility: The share of loosely bound $\mathrm{Cu}$ compounds was $24 \%$ of its total content in the soil. The increase in the content of loosely bound $\mathrm{Cu}$ compounds correlated with the application rate of the metal and was mainly due to its complexed forms Table 2 . A study of the fractional composition of $\mathrm{Cu}$ compounds in Haplic Chernozem (Minkina et al., 2008) showed that organic matter is significantly involved in the sorption of this element by the soil. A reliable increase in the $\mathrm{Cu}$ content was observed already at the application of 1 MPC for complexed and specifically sorbed forms and 2 MPC for exchangeable forms. The increase in the content of mobile $\mathrm{Cu}$ forms compared to the total metal content at the application of 1-5 MPC determined the increase in the share of specifically sorbed forms.

The content of mobile $\mathrm{Zn}$ forms in the Haplic Chernozem was $13 \%$ of the total content of the metal. The application of $\mathrm{Zn}$ at a rate of 1 MPC doubled the content of its loosely bound compoundsin the soil. When the contamination of soil with $\mathrm{Zn}$ increased, the contents of its mobile forms increased proportionally to the application rates mainly due to exchangeable and specifically sorbed forms Table 3and Fig. 1. As in the case of $\mathrm{Cu}$, a significant increase in the content of loosely bound $\mathrm{Zn}$ compounds was observed at the application of 5-10 MPC.

The contamination of soil with HMs resulted in a significant inhibition of the cellulose-degrading and urease activities of soil (Table 4). A reliable decrease in these parameters was noted already at a contamination rate of 1 MPC. An exclusion was provided by the treatment with the application of $\mathrm{Zn}$ at $1 \mathrm{MPC}$, where some increase in urease activity was noted for the incubation during 30 days. For cellulose-degrading activity, the HM contamination of soil was more toxic at the incubation for 30 days. The incubation during 60 days can be characterized by adaptation processes. For cellulose-degrading activity, adaptation processes were more manifested than for urease activity. The cellulose-degrading and urease activities of Haplic Chernozem were more inhibited by the excess amounts of $\mathrm{Cd}$ and, to a lesser extent, $\mathrm{Cu}$ in the soil.

At the contamination of soil with an HM, the decrease in cellulose-degrading and urease activities in most treatments correlated with the content of the added HM. The level of soil contamination with HMs at a rate of 1 MPC after composting for 30 days decreased the cellulose-degrading activity by 17 to $35 \%$ compared to the control. After the incubation for 60 days, this parameter varied from 7 to $23 \%$. For urease, a decrease in activity by $15-17 \%$ was noted after 30 days in the treatment with 1 MPC; after 60 days of incubation, the decrease was 9$23 \%$. After incubation for 60 days, cellulose-degrading activity increased by $22,23,10$ and $25 \%$ in the treatments with the application of $\mathrm{Zn}, \mathrm{Cd}, \mathrm{Cu}$ and $\mathrm{Pb}$, respectively.

The urease activity of soil was instable in the treatment with the application of 1 MPC. For example, an increase in urease activity compared to the control was noted for $\mathrm{Zn}$ at the composting for 30 days, as well as a decrease by $20 \%$ after 60 days of composting. According to some authors, low HM concentrations can activate the enzyme activity (Belyaeva, 2002; Grigoryan, 1990; Minnikova et al., 2017). Under Cd contamination, the activity of urease decreased by $17 \%$ after 30 days and returned to the control level (23\%) after 60 days. Similar changes were revealed at the application of $\mathrm{Cu}$ and $\mathrm{Pb}$. The activity of urease in the treatment with 1 MPC decreased by $15 \%$ compared to the control after 30 days of incubation and increased by 5-6\% after 60 days.

The contamination of Haplic Chernozem with HMs at a rate of $10 \mathrm{MPC}$ resulted in a higher decrease in cellulose-degrading activity and strongly depended on the metal nature. For example, the activity of cellulose-degrading organisms in the treatment with the addition of $\mathrm{Cd}$ decreased by $75 \%$ after 30 days of composting. However, this parameter increased by $16 \%$ after 60 days. An increase in activity of 16,8 and $2 \%$ was also observed for $\mathrm{Zn}, \mathrm{Pb}$ and $\mathrm{Cu}$, respectively. The urease activity of soil in this treatment was manifested differently. Further decrease in activity from $22 \%$ after 30 days to $41 \%$ after 60 days was noted for $\mathrm{Zn}$. A less significant decrease in urease activity was noted for the other studied metals: By $9 \%$ for $\mathrm{Cd}$, by $4 \%$ for $\mathrm{Pb}$ and by $3 \%$ for $\mathrm{Cu}$. Among all of the studied metals, $\mathrm{Cd}$ inhibited the biological activity of soil to the lowest degree.

Comparison of the contents of exchangeable, complexed and specifically sorbed HM compounds in the soil with the cellulose-degrading and urease activities revealed close inverse correlations (Table 5). The relationship between the cellulose-degrading activity and the content of mobile HM forms in the soil depended on the metal nature. The closest correlation with the studied parameters was revealed for $\mathrm{Zn}$ and $\mathrm{Cu}$. Correlation analysis showed that all of the studied HM forms had an inhibiting effect on parameters of soil biological activity. 
Natalia Gromakova et al. / OnLine Journal of Biological Sciences 2017, 17 (3): 143.150 DOI: 10.3844/ojbsci.2017.143.150

Table 4. Effect of HMs on the biological activity of soil, in $\%$ of the control

\begin{tabular}{|c|c|c|c|c|c|c|c|c|}
\hline \multirow[b]{2}{*}{ Experimental treatment } & \multicolumn{4}{|c|}{ Cellulose-degrading activity } & \multicolumn{4}{|c|}{ Urease activity } \\
\hline & $\mathrm{Zn}$ & $\mathrm{Cd}$ & $\mathrm{Cu}$ & $\mathrm{Pb}$ & $\mathrm{Zn}$ & $\mathrm{Cd}$ & $\mathrm{Cu}$ & $\mathrm{Pb}$ \\
\hline \multicolumn{9}{|l|}{ Composting for 30 days } \\
\hline Control & 100.0 & 100.0 & 100.0 & 100.0 & 100.0 & 100.0 & 100.0 & 100.0 \\
\hline $1 \mathrm{MPC}$ & 72.0 & 65.0 & 83.0 & 67.0 & 109.0 & 83.0 & 85.0 & 85.0 \\
\hline $2 \mathrm{MPC}$ & 70.0 & 57.0 & 79.0 & 62.0 & 95.0 & 74.0 & 78.0 & 80.0 \\
\hline $5 \mathrm{MPC}$ & 57.0 & 46.0 & 72.0 & 53.0 & 88.0 & 69.0 & 72.0 & 65.0 \\
\hline $10 \mathrm{MPC}$ & 46.0 & 25.0 & 62.0 & 39.0 & 78.0 & 42.0 & 58.0 & 52.0 \\
\hline $\mathrm{LSD}_{095}$ & 6.5 & 5.0 & 6.4 & 3.9 & 4.8 & 7.1 & 6.3 & 8.8 \\
\hline \multicolumn{9}{|l|}{ Composting for 60 days } \\
\hline Control & 100.0 & 100.0 & 100.0 & 100.0 & 100.0 & 100.0 & 100.0 & 100.0 \\
\hline $1 \mathrm{MPC}$ & 94.0 & 87.0 & 93.0 & 92.0 & 80.0 & 77.0 & 90.0 & 91.0 \\
\hline $2 \mathrm{MPC}$ & 86.0 & 70.0 & 87.0 & 81.0 & 70.0 & 76.0 & 83.0 & 81.0 \\
\hline $5 \mathrm{MPC}$ & 74.0 & 56.0 & 78.0 & 77.0 & 64.0 & 60.0 & 77.0 & 59.0 \\
\hline $10 \mathrm{MPC}$ & 62.0 & 41.0 & 64.0 & 47.0 & 59.0 & 51.0 & 61.0 & 56.0 \\
\hline $\mathrm{LSD}_{095}$ & 4.1 & 4.8 & 6.7 & 3.9 & 4.3 & 7.0 & 7.1 & 4.8 \\
\hline
\end{tabular}

Table 5. Correlation coefficients between heavy metal exchangeable form content in soil and biological activity

\begin{tabular}{|c|c|c|c|c|c|}
\hline \multirow[b]{3}{*}{ Element } & \multirow[b]{3}{*}{ Forms } & \multicolumn{4}{|c|}{ Incubation for } \\
\hline & & \multicolumn{2}{|c|}{ Cellulose-degrading activity } & \multicolumn{2}{|l|}{ Urease } \\
\hline & & 30 days & 60 days & 30 days & 60 days \\
\hline \multirow[t]{3}{*}{$\overline{Z n}$} & Exchangeable & -0.92 & -0.91 & -0.89 & -0.92 \\
\hline & Complexed & -0.95 & -0.93 & -0.87 & -0.93 \\
\hline & Specifically sorbed & -0.96 & -0.89 & -0.82 & -0.93 \\
\hline \multirow[t]{3}{*}{$\mathrm{Cd}$} & Exchangeable & -0.75 & -0.91 & -0.83 & -0.90 \\
\hline & Complexed & -0.74 & -0.92 & -0.90 & -0.92 \\
\hline & Specifically sorbed & -0.72 & -0.90 & -0.88 & -0.87 \\
\hline \multirow[t]{3}{*}{$\mathrm{Cu}$} & Exchangeable & -0.93 & -0.76 & -0.61 & -0.84 \\
\hline & Complexed & -0.94 & -0.75 & -0.59 & -0.86 \\
\hline & Specifically sorbed & -0.94 & -0.86 & -0.63 & -0.87 \\
\hline \multirow[t]{3}{*}{$\mathrm{Pb}$} & Exchangeable & -0.78 & -0.90 & -0.40 & -0.71 \\
\hline & Complexed & -0.79 & -0.90 & -0.40 & -0.78 \\
\hline & Specifically sorbed & -0.84 & -0.94 & -0.41 & -0.63 \\
\hline
\end{tabular}
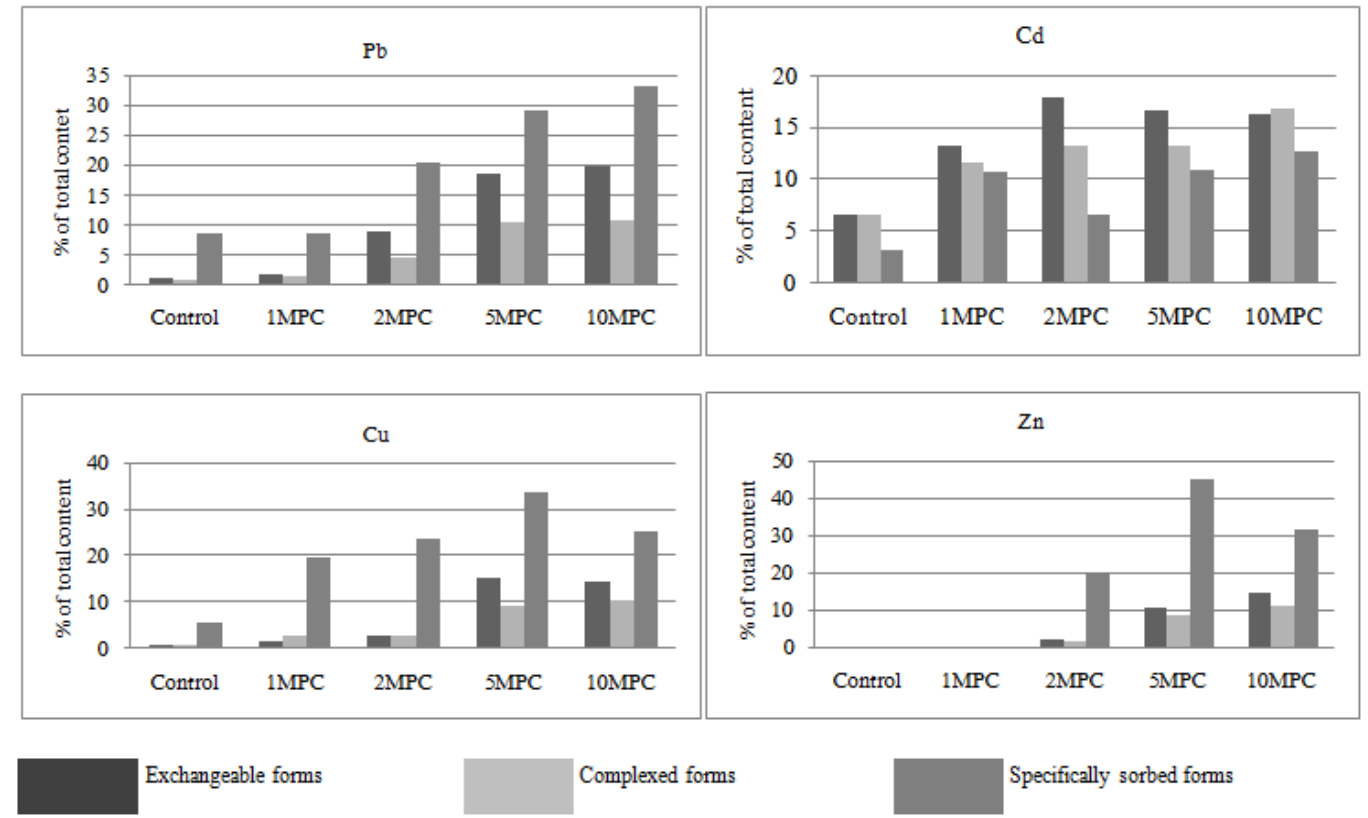

Fig. 1. Relative contents of loosely bound (exchangeable, complexed and specifically sorbed) HM forms in calcareous ordinary chernozem 


\section{Conclusion}

- In the uncontaminated Haplic Chernozem, a larger part of the $\mathrm{Zn}, \mathrm{Cu}, \mathrm{Cd}$ and $\mathrm{Pb}$ is firmly fixed by the soil components. The portion of loosely bound HM which includes exchangeable, complexed and specifically sorbed metal forms is $7-17 \%$ of their total contents

- Contamination of Haplic Chernozem with $\mathrm{Zn}, \mathrm{Cu}, \mathrm{Cd}$ and $\mathrm{Pb}$ increased the content of loosely bound metal compounds. The largest contribution was made by exchangeable and complexed metal forms. $\mathrm{Cu}$ was less mobile and $\mathrm{Cd}$ was the most mobile metals in the soil

- The increase in the content of loosely bound compounds of $\mathrm{Zn}, \mathrm{Cu}, \mathrm{Cd}$ and $\mathrm{Pb}$ in the soil resulted in a stable inhibition of cellulose-degrading and urease activities of soil during 30 days after the application of metals into the soil. A decrease in the toxic effect of metals on the studied parameters mainly occurred in the further 30 days

- By the degree of cellulose-degrading and urease activities inhibition, heavy metals formed the following series: $\mathrm{Cd}>\mathrm{Pb}>\mathrm{Zn}>\mathrm{Cu}$

\section{Acknowledgment}

This work was supported by the Ministry of Education and science of Russian Federation, project no. 5.948.2017/PP, Russian Foundation for Basic Research (RFBR), projects no. 16-05-00755, 16-35-60055.

\section{Author Contributions}

Natalia Gromakova and Saglara Mandzhieva: Participated in all experiments, coordinated the dataanalysis and contributed to the writing of the manuscript.

Tatiana Minkina, Galina Motuzova and Olga Birukova: Coordinated the data-analysis and contributed to the writing of the manuscript.

Sergey Kolesnikov and Natalia Barsova: Contributed in drafting the manuscript and reviewing it critically for significant intellectual content

Victor Chaplygin: Participated in all experiments, collected the field data performed the statistical analysis.

Inna Zamulina and Yurii Litvinov: Analyzed the soil, performed the statistical analysis.

Svetlana Sushkova: Collected the field data and contributed to the writing of the manuscript.

\section{Ethics}

This article is original and contains unpublished material. The corresponding author confirms that all of other authors have read and approved the manuscript and no ethical issues involved.

\section{References}

Artyushin, A.M., M.A. Florinskii, M.I. Lunev, E.N. Efremov and V.G. Sychev et al., 1992. Methodological guidelines on the determination of heavy metals in agricultural soils and crops. Tsinao, Moscow.

Bardina, T.V., M.V. Chugunova and V.I. Bardina, 2013. Study of ecotoxicity of urbanozems by methods of biotesting. Zhivye i Biokosnye Sistemy.

Belyaeva, O.N., 2002. Biological activity of ordinary chernozem and chestnut soil in the lower don region under anthropogenic impact. Cand. Sci. Biol. Dissertat., Rostov-on-Don.

Chaplygin, V.A., T.M. Minkina, S.S. Mandzhieva, S.N. Sushkova and O.G. Nazarenko et al., 2014. Steppe zone vegetation and soil layer pollution by heavy metals under the influence Novocherkassk power station emission. Biogeosy. Technique, 1: 50-57.

Dobrovol'skaya, T.G., D.G. Zvyagintsev, I.Y. Chernov, A.V. Golovchenko and G.M. Zenova et al., 2015. The role of microorganisms in the ecological functions of soils. Eur. Soil Sci., 48: 959-967.

Ershov, Y.A., 2005. General Chemistry: Biophysical Chemistry. 1st Edn., Chemistry of Biogenic Elements, Moscow.

Galstyan, A.S., 1982. Stability of soil enzymes. Pochvovedenie, 4: 108-110.

Grigoryan, K.V., 1990. Ecological estimation of a biocenosis component from soil enzyme activities under technogenic contamination. PhD Thesis, Moscow.

Gukalov, V.N., V.I. Savich and N.A. Trifonova, 2015. Stepwise changes of soil properties under contamination with heavy metals. Plodorodie, 1: 42-44.

$\mathrm{Hu}$, B., D. Liang, J.J. Liu, L.M. Lei and D. Yu, 2014.Transformation of heavy metal fractions on soil urease and nitratereductase activities in copper and selenium co-contaminated soil. Ecotoxicol. Environ. Saf., 110: 41-48.

Khaziev, F.K., 1982. Systemic and ecological analysis of soil enzyme activity. Nauka, Moscow.

Khaziev, F.K., 1990. Systemic and ecological analysis of soil enzyme activity. Moscow.

Kolesnikov, S.I., K.S. Kazev and V.F. Valkov, 2006. Ecological status and functions of soils under chemical contamination. Rostizdat Rostov-on-Don.

Kolesnikov, S.I., M.G. Zharkova, K.S. Kazeev, I.V. Kutuzova and L.S. Samokhvalova et al., 2014. Ecotoxicity assessment of heavy metals and crude oil based on biological characteristics of chernozem. Russian J. Ecol., 45: 157-166. 
Kolesnikov, S.I., M.V. Yaroslavtsev, N.A. Spivakova, M.G. Zharkova and K.S. Kazeev, 2013. Comparative assessment of the biological tolerance of chernozems in the South of Russia towards contamination with $\mathrm{Cr}, \mathrm{Cu}, \mathrm{Ni}$ and $\mathrm{Pb}$ in a model experiment. Eur. Soil Sci., 46: 176-181.

Mandzhieva, S.S., T.M. Minkina, S.N. Sushkova, G.V. Motuzova and T.V. Bauer et al., 2014. The group composition of metal compounds in soil as an index of soil ecological state. Am. J. Agric. Biol. Sci., 9: 19-24.

Mineev, V.G., L.A. Lebedeva and A.V. Arzamazova, 2008. Aftereffect of different fertilizing systems on the enzymatic activity of soddy-podzolic soil contaminated by heavy metals. Agrokhimiya. 10: 48-54.

Minkina, T.M., S.S. Mandzhieva, V.A. Chaplygin, T.V. Bauer and M.V. Burachevskaya et al., 2017a. Content and distribution of heavy metals in herbaceous plants under the effect of industrial aerosol emissions. J. Geochem. Explor., 174: 113120. DOI: 10.1016/j.gexplo.2016.05.011

Minkina, T.M., D.G. Nevidomskaya, T.N. Pol'shina, Y.A. Fedorov and S.S. Mandzhieva et al., 2017b. Heavy metals in the soil-plant system of the Don river estuarine region and the Taganrog bay coast. J. Soils Sediments, 17: 1474-1491.

Minkina, T.M., G.V. Motuzova, O.G. Nazarenko, V.S. Kryshchenko and S.S. Mandzhieva, 2008. Forms of heavy metal compounds in soils of the steppe zone. Eur. Soil Sci., 41: 810-818.

Minkina, T.M., N.N. Miroshnichenko, A.I. Fateev, G.V. Motuzova and S.S. Mandzhieva et al., 2015. Features of microelement composition of ordinary chernozems of the azov and lower don regions. Am. J. Agric. Biol. Sci., 10: 111-115. DOI: 10.3844/ajabssp.2015.111.115

Minnikova, T.V., T.V. Denisova, S.S. Mandzhieva, S.I. Kolesnikov and T.M. Minkina et al., 2017. Assessing the effect of heavy metals from the Novocherkassk power plant emissions on the biological activity of soils in the adjacent areas. J. Geochem. Explor., 174: 70-78.
Moreno, J.L., F. Bastida, M. Ros, T. Hernandez and C. Garcia, 2009. Soil organic carbon buffers heavy metal contamination on semiarid soils: Effects of different metal threshold levels on soil microbial activity. Eur. J. Soil Biol., 45: 220-228.

Motuzova, G.V., T.M. Minkina, E.A. Karpova, N.U. Barsova and S.S. Mandzhieva, 2014. Soil contamination with heavy metals as a potential and real risk to the environment. J. Geochem. Explor., 144: 241-246. DOI: 10.1016/j.gexplo.2014.01.026

Naplekova, N.N. and M.D. Stepanova, 1981. Effect of heavy metals (lead and cadmium) on microflora in leached chernozem and soddy-podzolic soil. Problems Metabolism Soil Microorganisms. Nauka, Novosibirsk.

Nedyalkova, K., R. Donkova and D. Deribeeva, 2017. Enzyme activity of Chromic Luvisols under different degree of erosion and land use. Euras. J. Soil Sci., 6: 37-43. DOI: 10.18393/ejss.284262

Sardar, K., 2007. Soil enzymatic activities and microbial community structure with different application rates of Cd and Pb. J. Environ. Sci., 19: 834-840.

Shipilina, N.N., 1996. Technogenically contaminated plowland soils and their bioindication. Cand. Scie. (Biol) Dissertation, Barnaul.

Shlevkova, E.I., 1993. Biological activity of southern chernozem depending on tillage practice. Pochvovedenie, 3: 40-44.

Usman, S., Y. Muhammad and A.M. Chiroman, 2016. Roles of soil biota and biodiversity in soil environment-A concise communication. Euras. J. Soil Sci., 5: 255-265. DOI: 10.18393/ejss.2016.4.255-265

Vodyanitskii, Y.N., 2014. Natural and technogenic compounds of heavy metals in soils. Eur. Soil Sci., 47: 255-265.

Zvyagintsev, D.G., 2001. Composition and functioning of a complex of soil microorganisms. Eur. Soil Sci., 34: $48-54$. 